\title{
A Comparative Study of Work Values between US and Malaysia Marketing Students
}

\author{
Ahmed Rageh Ismail ${ }^{1}$, Carol Johnson ${ }^{2}$, Bahtiar Mohamed ${ }^{3}$, Jafri Zulkepli ${ }^{4}$, Muhammad Awais Bhatti ${ }^{5} \&$ Linda Hii $^{1}$ \\ ${ }^{1}$ School of Business, Curtin University, Malaysia \\ 2 Daniels College of Business, University of Denver, USA \\ ${ }^{3}$ School of Multimedia Technology and Communication, Universiti Utara Malaysia, Malaysia \\ ${ }^{4}$ School of Quantitative Science, Universiti Utara Malaysia, Malaysia \\ ${ }^{5}$ School of Business, Universiti Utara Malaysia, Malaysia \\ Correspondence: Ahmed Rageh Ismail, Senior Lecturer, School of Business, Curtin University, Malaysia. Email: \\ Ahmed.r@curtin.edu.my
}

Received: August 3, 2016

Accepted: August 17, 2016

Online Published: August 28, 2016

doi:10.5430/ijba.v7n5p22

URL: http://dx.doi.org/10.5430/ijba.v7n5p22

\begin{abstract}
This paper aims to identify the ranking of importance of work values as perceived by marketing students, and to explore the underlying dimensions of work values in the Malaysian context. It also aims to determine whether there are differences of work values between marketing students in Malaysia and US. Previously validated Super's Work Values Inventory (SWVI) containing 15 dimensions was completed by business students undertaking Marketing and other majors in Malaysia and USA. Factor analysis is employed to examine the underlying structure of work values. The study confirms the two-factor structure (intrinsic and extrinsic) of work values and shows that marketing students value the work that allows them to fulfill their potential in terms of creativity $(M=4.23)$ and intellectual stimulation $(M=3.99)$ in Malaysia. Moreover, the results showed that significant differences in work values exist between Malaysia and US students with respect to economic return, way of life, altruism, prestige, management and variety. This article contributes to the worldwide knowledge on work values by highlighting the importance of understanding potential marketing professionals' work values in the two different countries. Respondents selected from two countries will limit the generalizability of the study.
\end{abstract}

Keywords: marketing students, work values, United States, Malaysia

\section{Introduction}

"Marketers, how can I decide if marketing is the right career for me? I am trying to decide whether to pursue marketing (my degree subject) as a career or try something totally different, and if anyone works in marketing I would find it really helpful to know the following: 1) what are the main things you love and hate about working in marketing? What is the main source of satisfaction for you? 2) How do you cope with the pressure of bottom-line accountability? Maybe I am looking at it the wrong way, but I feel in marketing there are always those who could second-guess you and feel someone else could have achieved better results with the same budget. Does this mean there are high turnovers in marketing positions as senior managers think someone else with "fresh ideas" will do better?"

(Questions post on www.ask.metafilter.com, 2010)

Values and beliefs are instilled in us by culture and play a significant role in our lives. These values are eventually used as guiding principles that justify our actions accordingly (Knafo and Schwartz, 2003). Generally, values are of interest to both academics and practitioners because they do not relate to a particular object or situation, are relatively few in numbers, and are stable overtime (Dose, 1997). Because of these characteristics, and in light of increasing trends towards internationalization and globalization, work values are an important medium through which employee behavior can be understood and managed. Traditionally, work values have been studied in the vocational psychology literature. Today's globalization is unavoidably spreading its influence around the world, especially in the managerial environment (Ghoshal, 2005) and it is essential to have a better understanding of the structure of 
marketing professionals' work values as they are the supposed experts of both sales and marketing. It is they who know the products, market, underlying technologies and the factors that cause customers to buy. It is also important to have a better understanding of the work values of the young generation in Asia Pacific countries in general, and Malaysia in particular, with regard to a specific job category, i.e. marketing and compare those values with their counterparts in US.

A number of studies examined the concept of work values (Hirschi, 2010; Gahan and Abesekera, 2009; Vansteenkiste et al., 2007; Zhang, 2007; Roe and Ester, 1999; Sagie at al., 1996) and the strong influence of work values on work performance (Klenke, 2005). Although work value is an important topic, little attention has been paid to it in marketing literature. It is important to know exactly what work values future marketers possess and what characteristics of work are important to them. According to the Attraction-Selection-Attrition (ASA) theory (Schneider et al., 1995) work values are an important determinant of person-organization fit. Individuals are attracted to an organization because of the values of the organization; they will be happier, more motivated, satisfied, and committed when the individual's values are congruent with those emphasized by their employer. Likewise, individuals will leave the organization if their values do not match those of the organization (Judge and Bretz, 1992). This basic idea goes back to Super (1953), who suggested that: "work satisfaction and life satisfaction depend upon the extent to which the individual finds adequate outlets for his abilities, interests, personality traits, and values ...". The proposition of Super sounds self-evident, especially for youngsters who still have to develop their careers. Furthermore, Dawis and Lofquist (1984) suggested that work values are central to understanding job satisfaction, as posited in their Theory of Work Adjustment (TWA) (Dawis and Lofquist, 1984), which assumes that individuals develop job satisfaction when their values are fulfilled by aspects of their job. Therefore, work values are believed to be critical in career choice (Super, 1953). The process of a career choice is argued to be complicated. While the concept of career is changing, students worldwide are usually facing challenges in their future career decision-taking. The choice of courses to study in business schools and the subsequent paths to follow, are fraught with problems.

Marketing is considered to be one of the "creative" areas of business, and a marketing professional is deemed to have creative tendencies which can build the dream, as well as possessing an analytical mind to research the market before developing appropriate strategies. There is always a need for marketing professionals in most companies, organizations and industries, be it a small or large business. In considering a career in marketing, it is important to select a job that best reflects that individual's values as this can make the difference between enjoying and detesting any future career, and dedicating oneself to career choices that are unattainable may lead to frustration. Therefore, the question is, what work values future marketing professionals hold? To date, in the marketing field, there has been a scarcity of research in this subject. Thus, the objective of this study is threefold: (1) to identify the ranking of importance of work values perceived by marketing students; (2) to identify the underlying work value structure among marketing undergraduate students, and (3)to determine whether there are differences of work values between marketing students in Malaysia and the United States.

In our study, we focused upon the Eastern and Western cultures. We selected Malaysia and USA because of the substantial differences between these cultures (Ronen and Shenkar, 1985). A major influence within the Eastern culture is Confucianism (Engardio, 1995) whereby importance of society, the group, and hierarchical relationships within a society has been endured for many years. In contrast, the Judeo-Christian religion has been the primary influence in the West which emphasizes on personal achievement and individual self-worth (Wayne 1989). Collectivism is represented in this study by Chinese Malaysian and Individualism is represented by US students.

\section{Literature Review}

Becker and McClintock (1967); Schwartz (1992) describe value as normative standards to choose among various behaviors. Values are widely considered to be central to the selection of life roles (Brown and Crace, 1996). Gordon (1975) suggested that values tend to remain fairly stable over an individual's life span. The literature provides a number of definitions of values; for example, Rokeach $(1973$, p.5) defines a value as "an enduring belief that a specific mode of conduct or end-state of existence is personally or socially preferable to an opposite or converse mode of conduct or end-state of existence". Super (1980, p.130) defines a value as "an objective, either a psychological state, a relationship, or material condition that one seeks to attain". Dose (1997, p. 220) summarizes and defines values as: ". . . standards or criteria for choosing goals or guiding action . . ." that are ". . . relatively enduring and stable over time". This definition can be applied to the meaning of work values by adding "relating to work or the work environment" (Dose, 1997, p. 227). Rokeach (1973) stated that "Values are determinants of virtually all kinds of behavior that could be called social behavior or social action, attitudes and ideology, evaluations, moral judgments and justifications of self and others, and attempts to influence others" ( p.5). The Rokeach Value 
Survey (Rokeach, 1973) found that values can be classified into two sets. The first set represents terminal values or the ultimate end-goals of existence, such as wisdom, equality, peace, family security and inner harmony as desirable end-states of existence. The second set represents instrumental values, or the behavioral means for achieving such end-goals, for instance, the importance of being honest, courageous, responsible, open-minded, ambitious, forgiving, or logical. The concept of work values is defined and measured in a variety of ways, depending on the research objectives and theoretical background (Dose, 1997; Meglino and Ravlin, 1998; Roe and Ester, 1999). Some authors consider work values as broad tendencies to prefer certain job characteristics, outcomes or features of work environments (e.g. Furnham, Forde, and Ferrari, 1999; Hofstede, 1998; Lofquist and Dawis, 1978; Pryor, 1982, Super, 1973), whereas others define them as desirable modes of behavior (Meglino and Ravlin, 1998). Another group (Jones, 1991; Trevino, 1986) describes values as systems of ethics, ideologies or philosophies. A work value, which is a specific context to which values can be applied, can be defined as the importance individuals give to a certain outcome obtained in a work context (Elizur, 1984). According to Ros, Schwartz, Surkiss (1999) work values are beliefs pertaining to desirable end states (e.g. high pay) or behaviours (e.g. working with people).

Many researchers suggest that work values can be classified as extrinsic or intrinsic (George and Jones, 1997; Nord, Brief, Atieh and Dohorty, 1990; Wollack et al., 1971). One definition describes intrinsic work values as desired end states depending on the content of work, and extrinsic values as independent content of the work (George and Jones, 1997). Examples of intrinsic work values include creativity and intellectual stimulation; examples of extrinsic work values include prestige and economic returns (Johnson, 2001). Super (1990) proposed the Life-Career Rainbow which suggested that a person would have different "roles," such as child, student, worker, and so on, throughout his or her entire lifespan. Work values play an important role in the development of each "role" (Super, 1990). Super (1957) developed a scale, Super's Work Values Inventory (SWVI), to measure work values. The SWVI included 15 statements and used a pair-comparison format. The 1970 version contained 15 dimensions: Altruism, Esthetics, Creativity, Intellectual Stimulation, Achievement, Independence, Prestige, Management, Economic Returns, Security, Surroundings, Supervisory Relations, Associates, Way of Life, and Variety. The latest version, Super's Work Values Inventory - Revised (SWVI-R), comprises 12 scales: Achievement, Coworkers, Creativity, Income, Independence, Lifestyle, Mental Challenge, Prestige, Security, Supervision, Work Environment, and Variety. Previous studies find very few gender differences between males and females regarding work values (Keller, Bourchard, Arvey, Segal, and Dawis, 1992; Rowe and Snizek, 1995). However, Taylor and Thompson (1976) investigated the differences of work value systems between younger and older workers, and the results indicated that both education and age had a strong influence on work values. Past research has shown that intrinsic and extrinsic work values are associated with different outcomes. For example, Hirschi (2010) found that intrinsic work values, such as personal growth, had a positive impact on career development. Vansteenkiste et al. (2007) confirmed that, employees with high extrinsic work values tend to place an excessive focus on external indicators of their worth, status, and importance.

The current study is built on the premise that values in general play a central role in determining work values, which in turn play a critical role in career choice. The relationship between general values - or beliefs - and work values has also been examined. For example, Hyde and Weathington (2006) addressed the relationship between personal-life values and work values. Duffy (2010) explored how intrinsic religiousness and spirituality influenced work values. Zhang et al. (2007) analyzed the relationship between work values and personality in Chinese students. Gahan and Abeysekera (2009) found that the effect of national culture on work values was mediated by individual self-construal (independent and interdependent). Demographics such as gender, age, and educational level, have been found to influence work values (Hagstrom and Kjellberg, 2007; Hirschi, 2010; Warr, 2008). The differences or similarities in work values across various countries with different national cultures have also been investigated (Hattrup, Muller, \& Aguirre, 2007; Hattrup et al., 2007; Wang et al., 2010; Warr, 2008).

In this study, the value system in the Malaysian context is addressed. The total Malaysian population is 28.3 million of which $91.8 \%$ are Malaysian citizens and $8.2 \%$ are non-citizens. Malaysian citizens are categorized into different ethnic groups; The Malays (Muslims) are the predominant ethnic group in Peninsular Malaysia which constitutes 67.4\%, followed by Chinese (Buddhism) 24.6\%, Indians 7.3\% and others 0.7\% (Department of Statistics, 2010). For the ethnically Chinese in Malaysia, the value system is derived from the Confucian ethos. Those values are universal in nature, but they also include some values which are uniquely Confucian (Hofstede, 1991) such as, respect for tradition, humility, filial piety, and protecting one's face. Furthermore, a system of guanxi or using connections to obtain something is integral to the very existence of society itself. This is often seen as a form of corruption from the west's point of view but, in fact, it forms a vital network of social relationships which are essential in Chinese culture. Moderation or following the middle way is another value leading to harmony and stability. These values support the collective rather than the individualistic way of thought and strengthen the construct of unity within the extended 
family unit. The value of non-competitiveness has raised the greatest controversy because of its overtly contradictory nature. It is classified here as part of the Confucian ethos. Many perceive ethnic Chinese as one of the most competitive of all peoples. This may, in fact, be true. However, self-perception and perceptions by others seem to be very different things. Chinese people consider aggressive competition to be an anathema. In the Western individualistic society this attitude is integral to sport and the attainment of goals. However, this overt competition and rivalry is considered a negative influence and manifestly rejected by Chinese society, but in business it would appear to be an acceptable course of action. Once again it may well be Western to evaluate an Eastern homeostatic mechanism in this way.

\section{Methods and Procedures}

The study aimed to identify the work values of senior marketing undergraduates in Malaysia. The data for this study was collected in the College of Business - Universiti Utara Malaysia (Malaysia). The study uses a student sample for its relative convenience. Also, it is assumed that the study of business students has some external validity in exploring their current and future work values. The usage of business students as a sample is especially advantageous. As the cultural values are rooted and developed through the growth of individuals, the ways in which they receive education and are influenced by family and peers, are especially relevant. Super's (1970) "Work Values Inventory" instrument is used and the WVI scale has 45 attributes. Each attribute is assessed on a five-point Likert-type scale ranging from "unimportant" to "very important" (See appendix 1). Undergraduate students were encouraged to participate in the study and voluntarily fill in a questionnaire that is written in English at the end of the lectures in their classrooms. 211 completed questionnaires were retained and analyzed. The respondents were from a Chinese ethnic background, and among the 211 respondents, 173 (77.8 \%) of them were female students. Although the Malay ethnic are majority in Malaysia as mentioned earlier, those who enrolled in marketing courses were Chinese. The value of Cronbach's alpha is 0.92 , which indicates a good internal consistency of the WVI. In the second phase of this study, Work Values Inventory" instrument is used again and self-administered questionnaires were presented also to other business disciplines (Accounting, finance, economic, international business, management and hospitality) in Univerisiti Utara Malaysia, and also to marketing students and other business fields at the University of Denver and Metropolitan State University of Denver in the United States of America. Then, the respondents were asked to rate how important the work values to them. A total of 324 usable questionnaires were collected, 150 were from other business fields in Malaysia, 46 were from marketing students in US and 128 from non-marketing students in US.

\section{Data Analysis and Results}

To explore the underlying factor structure of the WVI, EFA (Exploratory Factor Analysis) is used. Then CFA (Confirmatory Factor Analysis) is used to confirm the factorial structure derived from the EFA procedure. The sample size for this study met the minimum recommended level for performing EFA and CFA. Both the Bartlett test of sphericity and the Kaiser-Meyer-Olkin measure of sampling adequacy (0.925) showed that the sample met the criteria and was suitable for conducting factor analysis. Furthermore, the sample size met the criterion of having at least five observations for each variable (Anderson and Gerbing, 1988; Hair et al, 2006). Descriptive statistics of work values are given in Table 1. As Table 1 demonstrates, Achievement has the highest score of work values $(\mathrm{M}=4.31)$. It is followed by supervisory relations and creativity. Aesthetic is the lowest ranked value $(\mathrm{M}=3.78)$.

Table 1. Mean, standard deviation and correlation for the marketing students sample in Malaysia

\begin{tabular}{|c|c|c|c|c|c|c|c|c|c|c|c|c|c|c|c|c|c|}
\hline & $\mathrm{M}$ & S. D. & & 2 & 3 & 4 & 5 & 6 & 7 & 8 & 9 & 10 & 11 & 12 & 13 & 14 & 15 \\
\hline Achievement & 4.31 & 0.57 & 1.0 & & & & & & & & & & & & & & \\
\hline $\begin{array}{l}\text { Supervisor } \\
\text { relationships }\end{array}$ & 4.25 & 0.54 & 0.56 & 1.0 & & & & & & & & & & & & & \\
\hline Creativity & 4.23 & 0.64 & 0.39 & 0.27 & 1.0 & & & & & & & & & & & & \\
\hline Economic return & 4.06 & 0.56 & 0.41 & 0.46 & 0.24 & 1.0 & & & & & & & & & & & \\
\hline Surroundings & 4.05 & 0.57 & 0.52 & 0.52 & 0.32 & 0.43 & 1.0 & & & & & & & & & & \\
\hline Way of life & 4.05 & 0.54 & 0.48 & 0.47 & 0.33 & 0.46 & 0.49 & 1.0 & & & & & & & & & \\
\hline Altruism & 4.03 & 0.56 & 0.46 & 0.35 & 0.37 & 0.28 & 0.32 & 0.47 & 1.0 & & & & & & & & \\
\hline
\end{tabular}




\begin{tabular}{llllllllllllllllllll}
\hline Intellectual simulation & 3.99 & 0.56 & 0.44 & 0.26 & 0.53 & 0.33 & 0.36 & 0.35 & 0.46 & 1.0 & & & & & & \\
\hline Independence & 3.98 & 0.57 & 0.39 & 0.39 & 0.33 & 0.48 & 0.41 & 0.49 & 0.37 & 0.38 & 1.0 & & & & & \\
\hline Associates & 3.93 & 0.55 & 0.34 & 0.42 & 0.33 & 0.42 & 0.42 & 0.45 & 0.37 & 0.39 & 0.37 & 1.0 & & & & \\
\hline Security & 3.91 & 0.57 & 0.42 & 0.45 & 0.24 & 0.33 & 0.43 & 0.36 & 0.34 & 0.29 & 0.44 & 0.36 & 1.0 & & & \\
\hline Prestige & 3.86 & 0.58 & 0.46 & 0.35 & 0.42 & 0.43 & 0.45 & 0.45 & 0.39 & 0.41 & 0.47 & 0.45 & 0.38 & 1.0 & & \\
\hline Management & 3.84 & 0.62 & 0.44 & 0.29 & 0.42 & 0.31 & 0.34 & 0.42 & 0.42 & 0.52 & 0.44 & 0.37 & 0.30 & 0.55 & 1.0 & \\
\hline Variety & 3.81 & 0.56 & 0.29 & 0.26 & 0.42 & 0.62 & 0.33 & 0.39 & 0.29 & 0.35 & 0.35 & 0.33 & 0.28 & 0.38 & 0.34 & 1.0 \\
\hline Aesthetic & 3.78 & 0.60 & 0.39 & 0.26 & 0.61 & 0.52 & 0.34 & 0.33 & 0.47 & 047 & 0.40 & 0.31 & 0.25 & 0.37 & 0.45 & 0.34 & 1.0 \\
\hline
\end{tabular}

Using data from Malaysian respondents, factor analysis is conducted on 15 work value scores, which are calculated by summing up the 45 work value items. Principle component analysis with Varimax rotation was used to extract factors. Factors demonstrating an Eigen value greater than one were extracted, as the number of factors to be extracted are set using Eigen value $\geq 1$ as the main criterion (Pallant, 2001). Also, a scree plot was obtained to clarify if any other factors might be present (Tabachnik and Fidell, 2001). The resultant factor analysis is examined and items that show substantial and similar loadings on more than one factor are excluded (Hair et al, 2006). Similarly, items that demonstrate a factor loading of 0.4 or below are deleted from each resulting factor and then assessed using its Cronbach's alpha value. The initial factor analysis result reveals a two-factor solution, which accounts for $52 \%$ of variance. A close examination of factor loadings shows that "prestige" loads equally low on two factors, thus this item is removed and the analysis is re-run. The results of the EFA are presented in Table 2.

Table 2. Results of EFA (Exploratory Factor Analysis)

\begin{tabular}{lll}
\hline Work values & $\begin{array}{l}\text { Factor 1 } \\
\text { Extrinsic }\end{array}$ & $\begin{array}{l}\text { Factor 2 } \\
\text { Intrinsic }\end{array}$ \\
\hline Supervisor relationship & 0.78 & \\
Surroundings & 0.71 & \\
Economic return & 0.70 & \\
Way of life & 0.66 & \\
Security & 0.65 & \\
Achievement & 0.62 & \\
independence & 0.58 & \\
Associates & 0.57 & \\
\hline Intellectual simulation & & 0.82 \\
Creativity & & 0.78 \\
Aesthetics & & 0.72 \\
Management & & 0.68 \\
Altruism & & 0.56 \\
Variety & & 0.51 \\
\hline Cronbach alpha & 0.86 & 0.82 \\
\hline
\end{tabular}

Table 2 shows that the first factor has eight work value attributes and it accounts for $42 \%$ of variance. These variables are: security, supervisory relations, economic returns, achievement, associates, way of life, and surroundings. This factor is named "extrinsic values". The second factor contained six work value attributes, which accounts for $10 \%$ of variance. These variables are creativity, aesthetic, intellectual stimulation, management, altruism and variety. This factor is labeled "intrinsic values". Two first-order factors are hypothesized to underlie the 14 work value attributes (Figure 1). 


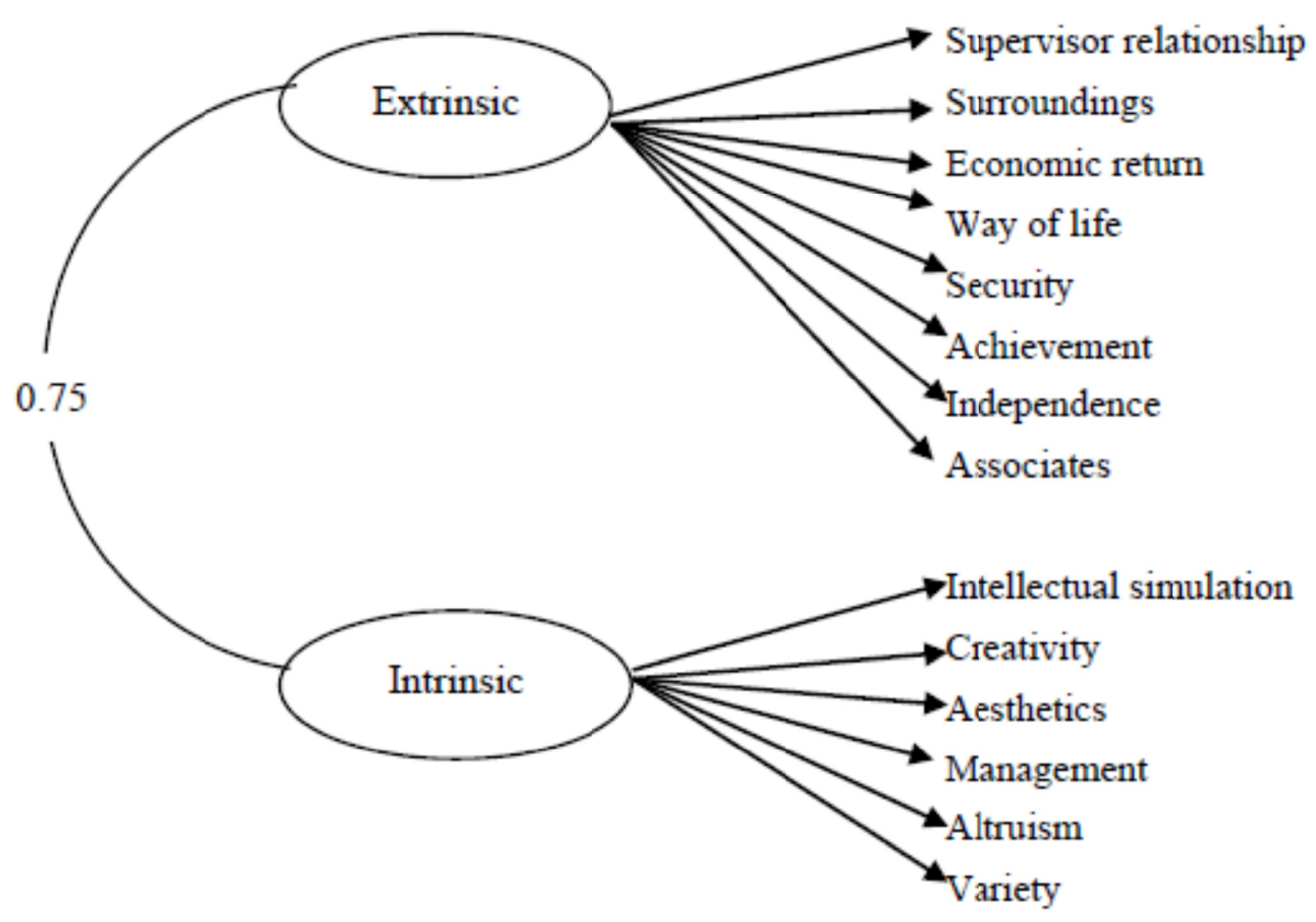

Figure 1. First-order work values structure

To confirm the factor structure found in EFA, the researcher conducts CFA using AMOS 6. Two first-order factors are examined, the results of the initial estimation of the first-order factor model provides a satisfactory result with a chi-square value of $119.190, \mathrm{df}=76, \mathrm{p}=0.001 \mathrm{CMIN} / \mathrm{DF}$ is 1.57 which is acceptable (Marsh and Hovecar, 1985). Other fit indices also reveal a good fit (RMSEA .052; CFI .96; GFI.93; AGFI.91; NFI .90).

Table 3. Results of CFA, composite reliability and variance extracted

\begin{tabular}{lllll}
\hline & & $\begin{array}{l}\text { Factor } \\
\text { loading }\end{array}$ & $\begin{array}{l}\text { Composite } \\
\text { reliability }\end{array}$ & $\begin{array}{l}\text { Average } \\
\text { Variance } \\
\text { Extracted }\end{array}$ \\
\hline Extrinsic & Supervisor relationship & 0.69 & & 0.66 \\
& Surroundings & 0.70 & 0.86 & \\
& Economic return & 0.63 & & \\
& Way of life & 0.71 & & \\
& Security & 0.59 & & 0.50 \\
& Achievement & 0.71 & & \\
& Independence & 0.65 & & \\
& Associates & 0.61 & & \\
Intrinsic & Intellectual simulation & 0.71 & & \\
& Creativity & 0.73 & & \\
& Aesthetic & 0.71 & 0.83 & \\
& Management & 0.69 & & \\
& Altruism & 0.63 & & \\
& Variety & 0.53 & & \\
\hline
\end{tabular}


Composite reliability is a principal measure used in assessing the overall reliability of the measurement model. For the two latent constructs in the model, composite reliability scores are greater than 0.70 (see Table 3 ), which indicates that the measures all consistently represent the same latent construct (Hair et al, 2006, Nunnally and Bernstein, 1994). Convergent validity is assessed by an item's own reliability and composite reliability (Anderson and Gerbing, 1988; Fornell and Larcker, 1981). Discriminant validity is assessed for the two constructs by constraining the estimated correlation parameter between them to 1.00 and then performing a chi-square difference test on the values obtained for the constrained and unconstrained model (Anderson and Gerbing, 1988). Nonetheless, all models in which the correlation constrained to one showed bad fit; therefore, discriminant validity was confirmed (Bagozzi and Philips, 1982). In summary, the measurement model should indicate good quality of reliability, convergent validity, and discriminant validity. It also shows that work values did not differ significantly by gender. The one-way ANOVA procedures employed identified that there is no significant work value differences between male and female $F(1,174)=.006, p>.001$ for the extrinsic values factor and $F(1,174)=5.490, p>.001$ for the intrinsic values factor.

The $t$-tests were undertaken to examine the significant differences between work values for different types of students (Marketing and Non-marketing; US and Malaysia). ANOVA tests with Duncan's multiple-range tests were also employed to explore significant differences among students groups from the two countries.

Table 4. Work values differences between marketing and non-marketing students in Malaysia

\begin{tabular}{lllll}
\hline Work values & $\begin{array}{l}\text { Malaysian marketing } \\
\text { students } \\
(N=211)\end{array}$ & $\begin{array}{l}\text { Malaysian } \\
\text { non-marketing students } \\
(N=150)\end{array}$ & t-value & significance \\
Achievement & 4.31 & 4.11 & 3.329 & 0.001 \\
Supervisor relationships & 4.25 & 4.04 & 3.247 & 0.001 \\
Creativity & 4.23 & 4.13 & 1.492 & 0.137 \\
Economic return & 4.06 & 3.83 & 3.374 & 0.001 \\
Surroundings & 4.05 & 3.96 & 1.399 & 0.163 \\
Way of life & 4.05 & 3.91 & 2.146 & 0.033 \\
Altruism & 4.03 & 3.96 & 1.249 & 0.213 \\
Intellectual simulation & 3.99 & 4.00 & -0.309 & 0.758 \\
Independence & 3.98 & 3.83 & 2.397 & 0.017 \\
Associates & 3.93 & 3.81 & 1.796 & 0.073 \\
Security & 3.91 & 3.73 & 2.751 & 0.006 \\
Management & 3.84 & 3.78 & 0.976 & 0.330 \\
Variety & 3.81 & 3.79 & 0.231 & 0.817 \\
Aesthetic & 3.78 & 3.74 & 0.674 & 0.501 \\
\hline
\end{tabular}

Table 4 shows work values differences in means between marketing and non-marketing students in Malaysia using t-test. The test reveals that six work values were significantly different between the two groups, namely, achievement, supervisory relationships, economic return, way of life, independence and security. No significant differences were found between marketing and non-marketing students in Malaysia with respect to other eight work values, i.e. creativity, surroundings, altruism, intellectual simulation, associates, management, variety and aesthetic. Malaysian marketing students appeared to have higher mean scores for achievement value than non-marketing students. In other words, Malaysian marketing students prefer job which gives one the feeling of accomplishment in doing a job well compared to their counterparts from other disciplines. Also, the mean scores suggested that marketing students in Malaysia place high importance on supervisory relationships than other non-marketing students. The results also indicated that marketing students in Malaysia are likely to select a job which pays well and enables them to have things they want more than other students. Furthermore, the way of life value or the work that permits one to live the kind of life he/she chooses and to be the type of person he/she wishes to be is reported to high in marketing students than non-marketing students in Malaysia. Moreover, the mean scores indicated that marketing students in Malaysia 
are more likely to search for work which permits one to work in his/her own way, as fast or slow as he/she wishes. Finally, marketing students in Malaysia place more importance on security more than non-marketing students.

Table 5. Work values differences between Malaysian and US marketing students

\begin{tabular}{lllll}
\hline Work values & $\begin{array}{l}\text { Malaysian marketing } \\
\text { students } \\
(N=211)\end{array}$ & $\begin{array}{l}\text { American marketing } \\
\text { students } \\
(N=46)\end{array}$ & t-value & significance \\
\hline Achievement & 4.31 & 4.38 & -0.691 & 0.490 \\
\hline Supervisor relationships & 4.25 & 4.40 & -1.620 & 0.106 \\
\hline Creativity & 4.23 & 4.29 & -0.525 & 0.600 \\
\hline Economic return & 4.06 & 4.41 & -3.571 & 0.000 \\
\hline Surroundings & 4.05 & 4.06 & -0.077 & 0.939 \\
\hline Way of life & 4.05 & 4.64 & -6.789 & 0.000 \\
\hline Altruism & 4.03 & 4.27 & -2.418 & 0.016 \\
\hline Intellectual simulation & 3.99 & 3.96 & -0.304 & 0.761 \\
\hline Independence & 4.12 & 4.23 & -1.182 & 0.238 \\
\hline Associates & 3.93 & 4.02 & -1.001 & 0.318 \\
\hline Security & 3.91 & 4.09 & -1.785 & 0.076 \\
\hline Management & 3.84 & 3.55 & 2.668 & 0.008 \\
\hline Variety & 3.81 & 4.08 & -2.871 & 0.004 \\
\hline Aesthetic & 3.78 & 3.64 & 1.391 & 0.166 \\
\hline
\end{tabular}

According to Table 5, marketing students in Malaysia and US show similar work values, the results of t-tests showed that Marketing students in Malaysia were not statistically significantly different from US students with respect to 9 work values, namely, achievement, supervisory relationships, creativity, surroundings, intellectual simulation, independence, associates, security and aesthetic. By contrast, statistically significant differences were found between Malaysian marketing students and American marketing students with respect to five work values: economic return, way of life, altruism, management and variety. The mean scores suggest that American marketing students tend to place high importance on those factors with exception of management work value. Furthermore, American marketing students are more likely to find a job which pays well and enables them to have things they want compared to Malaysian students. They are also more likely to have a job that permits one to live the kind of life he/she chooses and to be the type of person he/she wishes to be in comparison to Malaysian counterparts. Furthermore, the altruism value or work which enables one to contribute to the welfare of others reported to be high in American marketing students than marketing students in Malaysia. Moreover, the mean scores indicated that marketing students in America are more likely to search for work which gives one standing on the eyes of others and evokes respect. Finally, marketing students in America place more importance on work that provides an opportunity to do different types of tasks. As for the Malaysian students, they scored higher than Americans in terms of management work values which permits one to plan and lay out work for others.

Table 6. Work values differences between US marketing and non-marketing students

\begin{tabular}{lllll}
\hline Work values & $\begin{array}{l}\text { American non- } \\
\text { marketing students } \\
(N=118)\end{array}$ & $\begin{array}{l}\text { American marketing } \\
\text { students } \\
(N=46)\end{array}$ & t-value & significance \\
\hline Achievement & 4.29 & 4.38 & 0.933 & 0.352 \\
\hline Supervisor relationships & 4.24 & 4.40 & 1.490 & 0.138 \\
\hline Creativity & 3.90 & 4.29 & 3.027 & 0.003 \\
\hline Economic return & 4.42 & $4 . .41$ & -0.116 & 0.908 \\
\hline Surroundings & 4.07 & 4.06 & -0.112 & 0.911 \\
\hline
\end{tabular}




\begin{tabular}{lllll}
\hline Way of life & 4.53 & 4.64 & 1.296 & 0.197 \\
\hline Altruism & 3.85 & 4.27 & 3.062 & 0.003 \\
\hline Intellectual simulation & 3.82 & 3.96 & 1.305 & 0.194 \\
\hline Independence & 3.88 & 4.23 & 3.051 & 0.003 \\
\hline Associates & 3.95 & 4.02 & 0.617 & 0.538 \\
\hline Security & 3.91 & 4.09 & 1.312 & 0.191 \\
\hline Management & 3.55 & 3.56 & 0.083 & 0.934 \\
\hline Variety & 3.88 & 4.08 & 1.674 & 0.096 \\
\hline Aesthetic & 3.14 & 3.64 & 3.198 & 0.002 \\
\hline
\end{tabular}

Table 6 showed that no statistically significant differences in work values existed between marketing students and other students in US with the exception of four values, namely, independence, altruism, creativity and aesthetic.

\section{Discussion and Conclusion}

Throughout life individuals acquire a set of values, beliefs and ideas that are important to them and live their lives according to this set of values. Matching an individual's work values with characteristics of occupations is a key success factor that should be considered. Therefore, the purpose of this study was to identify the work value structure of marketing students in Malaysia and to make a comparison of work values between Marketing students in US and Malaysia. A work value inventory is used by career counselors and career development facilitators to measure how important various work values are to the individual. Similarly, in this study a work value inventory is used to assess the importance of different attributes of work values so that marketing departments at different firms can understand what students value the most in work activities, so that they can develop effective recruitment strategies as well as effective employee retention programs. Data were collected from senior marketing and non- marketing students in US and Malaysia. EFA and CFA were conducted to explore and confirm students' work value structure. A two-factor work value structure, including extrinsic and intrinsic, emerge after EFA on the first run. This structure is then subjected to CFA, the results of CFA confirmed the presence of the factorial structure of work values. Extrinsic values factor represents work values such as security, supervisory relations, economic returns, associates, achievement, surroundings, and way of life. The extrinsic factor of work value involves most of the tangible work outcomes. The other factor, "intrinsic values", represents more intangible aspects of work. For example, six work values are grouped into the factor of "Intrinsic values". They are creativity, aesthetic, intellectual stimulation, management, altruism and variety. These values relate to the intangible aspects of jobs that allow job holders to fulfill their talents. The two first-order factors organize, as well as summarize, the 14 work values into broader categories.

With regard to the Malaysian sample, achievement is the work value that marketing students appreciate most, and that specific value is generally emphasized in Asian culture where individuals believe in constant perseverance in order to achieve their goals $(\mathrm{Li}, 2004)$. This study shows that marketing students value the work that allows them to fulfill their potential in terms of creativity (mean $=4.23$ ) and intellectual stimulation (mean $=3.99$ ). Apparently, a career in marketing can mean many things; it may involve working in promotion, branding, communications, advertising, sales jobs or market research. The job is stimulating because it requires marketing professionals to be creative. Moreover, the influence of the Chinese heritage (most of the respondents are from a Chinese ethnic background) is demonstrated how much Malaysian students care about interpersonal relationships, or "quanxi." They are particularly concerned about their personal relationships with supervisors. Also, that finding reflects their "Respect for an authority figure", and is a value which emphasizes the high regard and admiration they hold for an authority figure (Kim and Hong, 2004). Having a good salary (economic returns), working in a pleasant environment (surroundings), and living out the life of their dreams (way of life) are important to them. Females made up $77.8 \%$ of the marketing students in Malaysia samples. The work value structure identified in this sample is more representative of female employees' work values than those of their male counterparts. Additionally, the study reports that work values do not differ significantly between male and female workers and this result is congruent with previous studies which found very few gender differences between males and females (Keller, Bourchard, Arvey, Segal, and Dawis, 1992; Rowe and Snizek, 1995).

The findings of the study suggest that marketing students in Malaysia and US show similar work values with respect to nine work values, namely, achievement, supervisor relationship, creativity, surroundings, intellectual simulation, 
independence, associates, security and aesthetic. By contrast, statistically significant differences were found between Malaysian marketing students and American marketing students with respect to other work values: economic return, way of life, altruism, management and variety. The mean scores suggest that American marketing students tend to place high importance on those five factors. Furthermore, American marketing students are more likely to find a job which pays well and enables them to have things they want compared to Malaysian students. They are also more likely to have a job that permits one to live the kind of life he/she chooses and to be the type of person he/she wishes to be in comparison to Malaysian counterparts. Furthermore, the altruism value or work which enables one to contribute to the welfare of others reported to be high in American marketing students than marketing students in Malaysia. Moreover, the mean scores indicated that marketing students in America are more likely to search for work which gives one standing on the eyes of others and evokes respect. Finally, marketing students in America place more importance on work that provides an opportunity to do different types of tasks. As for the Malaysian students, they scored higher than Americans in terms of management work values which permits one to plan and lay out work for others. The current study findings are consistent with previous research that showed work values vary by job category i.e. nurses (Cooman et al., 2008) and IT professionals (Dinger, Thatcher, and Stepina, 2010). This article contributes to the current knowledge on work values by pinpointing the importance of understanding potential marketing professionals' work values in the two different cultures. It is believed that understanding the work values of senior marketing students may enable firms to make the fullest use of their talents. The main limitation of this study is in the generalizability of the work value structure. Therefore, it is suggested that more cross-cultural comparison studies to be conducted to examine the possibility of generalizing the factor structure onto different subjects with different cultural backgrounds. In addition, these findings warrant further investigation on the impact of social/cultural variables on work values.

\section{References}

Anderson, J.C., \& Gerbing, D.W. (1988). Structural equation modeling in practice: A review and recommended two-step approach. Psychological Bulletin, 103, 411-423. http://dx.doi.org/10.1037/0033-2909.103.3.411

Askmetafilter. (2010). Ask Meta Filter. Retrieved $2^{\text {nd }}$ Feb. 2013, from http://www.ask.metafilter.com

Bagozzi, R.P., \& Phillips, L.W. (1982). Representing and testing organizational theories: A holistic construal. Administrative Science Quarterly, 27, 459-489. http://dx.doi.org/10.2307/2392322

Becker, G.M., \& McClintock, G.C. (1967). Value-behavioral decision theory. Annual Review of Psychology, 18, 239-86. http://dx.doi.org/10.1146/annurev.ps.18.020167.001323

Brown, D., \& Crace, R. K. (1996). Values in life role choices and outcomes: A conceptual model. The Career Development Quarterly, 44, 211-223. http://dx.doi.org/10.1002/j.2161-0045.1996.tb00252.x

Cooman, R., Dieter, S., Pepermans, R., Bois, C., Caers, R., \& Jegers, M. (2008). Freshmen in nursing: Job motives and work values of a new generation. Journal of Nursing Management, 16(1), 56-64. http://dx.doi.org/10.1111/j.1365-2934.2007.00800.x

Dawis, R. V., \& Lofquist, L. H. (1984). A psychological theory of work adjustment. Minneapolis: University of Minnesota Press.

Department of Statistics, M. O. (2010). Department of Statistics, Malaysia Official Website. Retrieved 16 November 2012 ,

from http://www.statistics.gov.my/portal/index.php?option=com_content\&view=article\&id=1215\%3Apopulation-dis tribution-and-basic-demographic-characteristic-report-population-and-housing-census-malaysia-2010-updated-2 972011\&catid $=130 \% 3$ Apopulation-distribution-and

Dinger, M., Thatcher, J. B., \& Stepina, L. P. (2010). A study of work-family conflict among IT professionals: Job characteristics, individual values, and management practices. Journal of Organizational Computing and Electronic Commerce, 20(1), 91-121 http://dx.doi.org/10.1080/10919390903482341

Dose, J. J. (1997). Work values: An integrative framework and illustrative application to organizational socialization. Journal of Occupational and Organizational Psychology, 70, 219-240. http://dx.doi.org/10.1111/j.2044-8325.1997.tb00645.x

Duffy, R. D. (2010). Spirituality, religion, and work values. Journal of Psychology and Theology, 38(1), 52-61.

Elizur, D. (1984). Facets of work values: A structural analysis of work outcomes. Journal of Applied Psychology, 69, 379-389. http://dx.doi.org/10.1037/0021-9010.69.3.379 
Engardio, Pete. (1995). China: Move over, Karl Marx - Here comes Confucius. Business Week, May 29, 53.

Fornell, C., \& Larcker, D.F. (1981). Evaluating structural equation models with unobservable variables and measurement errors. Journal of Marketing Research, 18, 39-50. http://dx.doi.org/10.2307/3151312

Furnham, A., Forde, L., \& Ferrari, K. (1999). Personality and work motivation. Personality and Individual Differences, 26, 1035-1043. http://dx.doi.org/10.1016/S0191-8869(98)00202-5

Gahan, P., \& Abeysekera, L. (2009). What shapes an individual's work values? An integrated model of the relationship between work values, national culture and self-construal. International Journal of Human resource Management, 20(1), 126-147. http://dx.doi.org/10.1080/09585190802528524

George, J., \& Jones, G. (1997). Experiencing work: Values, attitudes, and moods. Human Relations, 50, 393-416. http://dx.doi.org/10.1177/001872679705000404

Ghoshal, S. (2005). Bad management theories are destroying good management practices. Academy of Management Learning \& Education, 4(1), 75-91. http://dx.doi.org/10.5465/AMLE.2005.16132558

Gordon, L. V. (1975). The measurement of interpersonal values. Chicago: Science Research Associates.

Hagstrom, T., \& Kjellberg, A. (2007). Stability and change in work values among male and female nurses and $\begin{array}{lllll}\text { engineers. Scandinavian } & \text { Journal of Psychology, } & 48(2) & 143-151 .\end{array}$ http://dx.doi.org/10.1111/j.1467-9450.2007.00576.x

Hair, J.F., Anderson, R.E., Tatham, R.L., \& Black, W.C. (2006). Multivariate Data Analysis (5th ed.). Upper Saddle River, NJ: Prentice Hall.

Hattrup, K., Mueller, K., \& Aguirre, P. (2007). Operationalizing value importance in cross-cultural research: Comparing direct and indirect measures, Journal of Occupational and Organizational Psychology, 80(3). 499-513. http://dx.doi.org/10.1348/096317906X130843

Hattrup, K., Mueller, K., \& Joens, I. (2007). The effects of nations and organizations on work value importance: A cross-cultural investigation. Applied Psychology: An International Review, 56(3), 479-499

Hirschi, A. (2010). Positive adolescent career development: The role of intrinsic and extrinsic work values. Career Development Quarterly, 58(1), 276-287. http://dx.doi.org/10.1002/j.2161-0045.2010.tb00193.x

Hofstede, G. (1991). Cultures and organizations: Software of the mind. London: McGraw.

Hofstede, G. (1998). Attitudes, Values and Organizational Culture: Disentangling the concepts. Organization Studies, 19(3), 477. http://dx.doi.org/10.1177/017084069801900305

Hyde, R. E., \& Weathington, B. L. (2006). The congruence of personal life values and work attitudes. Genetic, Social \& General Psychology Monographs, 132(2). 151-190. http://dx.doi.org/10.3200/MONO.132.2.151-192

Johnson, Monica Kirkpatrick. (2001). Change in Job Values during the Transition to Adulthood. 28 Work and Occupations, 315-45. http://dx.doi.org/10.1177/0730888401028003004

Jones, T. M. (1991). Ethical decision making by individuals in organizations: an issue contingent model. Academy of Management Review, 16, 366-395.

Judge, T. A., \& Bretz, R. D., Jr. (1992). Effects of work values on job choice decisions. Journal of Applied Psychology, 77, 261-271. http://dx.doi.org/10.1037/0021-9010.77.3.261

Keller, L. M., Bouchard, T. J., Arvey, R. D., Segal, N. L., \& Dawis, R. V. (1992). Work values: Genetic and environmental influences. Journal of Applied Psychology, 77, 79-88. http://dx.doi.org/10.1037/0021-9010.77.1.79

Kim, B. S. K., \& Hong, S. (2004). A psychometric revision of the Asian Values Scale using the Rasch model. Measurement and Evaluation in Counseling and Development, 37, 15-27.

Klenke, K (2005). Introducing spirituality. International Journal of Organizational Analysis, 13(1), 4-8. http://dx.doi.org/10.1108/eb028994

Knafo, A., \& Schwartz, S.H. (2003). Parenting and adolescents' accuracy in perceiving parental values. Child development, 74(2), 595-611. http://dx.doi.org/10.1111/1467-8624.7402018

Li, J. (2004). Learning as a Task or a Virtue: U.S. and Chinese Preschoolers Explain Learning. Developmental Psychology, (40), 595-605. http://dx.doi.org/10.1037/0012-1649.40.4.595 
Lofquist, L. H., \& Dawis, R. V. (1978). Values as second-order needs in the theory of work adjustment. Journal of Vocational Behavior, 12, 12-19. http://dx.doi.org/10.1016/0001-8791(78)90003-9

Marsh, H.W., \& Hovecar, D. (1985). Application of confirmatory factor analysis to the study of self-concept: First and higher order factor models and their invariance across groups. Psychological Bulletin, 97, 562-582. http://dx.doi.org/10.1037/0033-2909.97.3.562

Meglino, B. M., \& Ravlin, E. C. (1998). Individual values in organizations: Concepts, controversies, and research. Journal of Management, 24, 351-389. http://dx.doi.org/10.1177/014920639802400304

Nord, W. R., Brief, A. P., Atieh, J. M., \& Doherty, E. M. (1990). Studying meanings of work: The case of work values. In A. P. Brief \&W. R. Nord (Eds.), Meanings of occupational work (pp. 21- 34). Lexington, MA: Lexington Books.

Nunnally, J.C., \& Bernstein, I.H. (1994). Psychometric Theory (3rd ed.). New York, McGraw-Hill.

Pallant, J. (2001). SPSS Survival Manual. Maidenhead, PA: Open University Press.

Pryor, R. (1982). Values, preferences, needs, work ethics, and orientations to work: Toward a conceptual and empirical integration. Journal of Vocational Behavior, 20, 40-52. http://dx.doi.org/10.1016/0001-8791(82)90062-8

Roe, R.A., \& Ester, P. (1999). Values and work: Empirical findings and theoretical perspective. Applied Psychology: An International Review, 48(1), 1-21. http://dx.doi.org/10.1111/j.1464-0597.1999.tb00046.x

Rokeach, M. (1973). The Nature of Human Values. The Free Press \& Macmillan Publishing Co., Inc., New York, NY.

Ronen, Simcha, \& Oded Shenkar. (1985). Clustering countries on attitudinal dimensions: A review and synthesis. Academy of Management Review, 10(3), 435-54.

Ros, M., Schwartz, S. H., \& Surkiss, S. (1999). Basic individual values, work values, and the meaning of work. Applied Psychology: An International Review, 48, 49-71. http://dx.doi.org/10.1111/j.1464-0597.1999.tb00048.x

Rowe, R., \& Snizek, W. E. (1995). Gender differences in work values: Perpetuating the myth. Work and Occupations, 22, 215-229. http://dx.doi.org/10.1177/0730888495022002005

Sagie, A., Elizur, D., \& Koslowsky, M. (1996). Work values: a theoretical overview and a model of their effects, $\begin{array}{lllll}\text { Journal of } & \text { Organizational } & \text { Behavior, } & \text { 17, } & \text { 5034. }\end{array}$ http://dx.doi.org/10.1002/(SICI)1099-1379(199612)17:1+<503::AID-JOB820>3.0.CO;2-Q

Schneider, B., Goldstein, H. W., \& Smith, D. B. (1995). The ASA framework: An update. Personnel Psychology, 48, 747-773. http://dx.doi.org/10.1111/j.1744-6570.1995.tb01780.x

Schwartz, S.H. (1992). Universals in the content and structure of values: theoretical advances and empirical tests in 20 countries. In Zanna, M.P. (Ed.), Advances in Experimental Social Psychology (25, pp. 1-65). Academic Press, San Diego, CA. http://dx.doi.org/10.1016/s0065-2601(08)60281-6

Super, D. E. (1953). A theory of vocational development. American Psychologist, 8, 186-195. http://dx.doi.org/10.1037/h0056046

Super, D. E. (1957). The psychology of careers. New York: Harper \& Row.

Super, D. E. (1973). The work values inventory. In D. G. Zytowski (Ed.), Contemporary approaches to interest measurement (pp. 189-205). Minneapolis, MN: University of Minnesota Press.

Super, D. E. (1980). A life-span, life-space approach to career development. Journal of Operational Psychology, 52, 129-148.

Super, D. E. (1990). A life-span, life-space approach to career development. In D. Brown \& L. Brooks (Eds.), Career choice and development: Applying contemporary theories to practice (2nd ed., pp. 197-261.) San Francisco: Jossey-Bass.

Tabachnick, B.G., \& Fidell, L.S. (2001). Using multivariate statistics (4th ed.). Boston: Allyn \& Bacon.

Taylor, R. N., \& Thompson, M. (1976). Work value systems of young workers. Academy of Management Journal, 19, 522-535. http://dx.doi.org/10.2307/255788

Trevino, L. K. (1986). Ethical decision making in organizations: person-situation interactionist model. Academy of Management Review, 11, 601-617. 
Vansteenkiste, M., Neyrinck, B., Niemiec, C., Soenens, B., De Witte, H., \& Van den Broeck, A. (2007). On the relations among work value orientations, psychological need satisfaction, and job outcomes: A self-determination theory approach. Journal of Occupational and Organizational Psychology, 80, 251-277. http://dx.doi.org/10.1348/096317906X111024

Wang, C. Y., Chen, M. H., Hyde, B., \& Hsieh, L. (2010). Chinese employees' work values and turnover intentions in multinational companies: The mediation effect of pay satisfaction. Social Behavior and Personality, 38(7), 871-894. http://dx.doi.org/10.2224/sbp.2010.38.7.871

Warr, P. (2008). Work values: Some demographic and cultural correlates. Journal of Occupational and Organizational Psychology, 81(4), 751-775. http://dx.doi.org/10.1348/096317907X263638

Wayne, F. Stanford. (1989). An instrument to measure adherence to the Protestant Ethic and contemporary work values. Journal of Business Ethics, 8, 793-804. http://dx.doi.org/10.1007/BF00383779

Wollack, S., Goodale, J. G., Witjing, J. P., \& Smith, P.C. (1971). Development of the survey of work values. Journal of Applied Psychology, 55, 331-338. http://dx.doi.org/10.1037/h0031531

Zhang, D., Wang, D., Yang, Y., \& Teng, F. (2007). Do personality traits predict work values of Chinese college students? Social Behavior and Personality, 35(9), 1281-1294. http://dx.doi.org/10.2224/sbp.2007.35.9.1281

\section{Appendix 1}

The statements below represent values which people consider important in their work. These are satisfactions which people often seek in their jobs or as a result of their jobs. They are not all considered equally important; some are very important to some people but of little importance to others. Read each statement carefully and indicate how important it is to you.

$$
\begin{aligned}
& \mathbf{5} \text { means "Very Important" } \\
& \mathbf{4} \text { means "Important" } \\
& \mathbf{3} \text { means "Moderately Important" } \\
& \mathbf{2} \text { means "Of Little Importance" } \\
& \mathbf{1} \text { means "Unimportant" }
\end{aligned}
$$

\section{WORK IN WHICH YOU:}

\section{CIRCLE ONE}

1. have to keep solving problems

2. help others

3. can get a raise

4. look forward to changes in your job

5. have freedom in your area

6. gain prestige in your field

7. need to have artistic ability

8. are one of the gang

9. know your job will last

10. can be the kind of person you would like to be

11. have a boss who gives you a fair deal

12. like the setting in which your work is done

13. get the feeling of having done a good day's work

14. have authority over others

$\begin{array}{lllll}5 & 4 & 3 & 2 & 1 \\ 5 & 4 & 3 & 2 & 1 \\ 5 & 4 & 3 & 2 & 1 \\ 5 & 4 & 3 & 2 & 1 \\ 5 & 4 & 3 & 2 & 1 \\ 5 & 4 & 3 & 2 & 1 \\ 5 & 4 & 3 & 2 & 1 \\ 5 & 4 & 3 & 2 & 1 \\ 5 & 4 & 3 & 2 & 1 \\ 5 & 4 & 3 & 2 & 1 \\ 5 & 4 & 3 & 2 & 1 \\ 5 & 4 & 3 & 2 & 1 \\ 5 & 4 & 3 & 2 & 1 \\ 5 & 4 & 3 & 2 & 1\end{array}$


15. try out new ideas and suggestions

16. create something new

17. know by the results when you've done a good job

18. have a boss who is reasonable

19. are sure of always having a job

20. add beauty to the world

21. make your own decisions

22. have pay increases that keep up with the cost of living

23. are mentally challenged

24. use leadership abilities

25. have adequate lounge, toilet and other facilities

26. have a way of life, while not on the job, that you like

27. form friendships with your fellow employees

28. know that others consider your work important

29. do not do the same thing all the time

30. feel you have helped another person

31. add to the well-being of other people

32. do many different things

33. are looked up to by others

34. have good connections with fellow workers

35. lead the kind of life you most enjoy

36. have a good place in which to work (quiet, calm, etc.)

37. plan and organize the work of others

38. need to be mentally alert

39. are paid enough to live very well

40. are your own boss

41. make attractive products

42. are sure of another job in the company if your present job ends

43. have a supervisor who is considerate

44. see the result of your efforts

45. contribute new ideas

$\begin{array}{lllll}5 & 4 & 3 & 2 & 1 \\ 5 & 4 & 3 & 2 & 1 \\ 5 & 4 & 3 & 2 & 1 \\ 5 & 4 & 3 & 2 & 1 \\ 5 & 4 & 3 & 2 & 1 \\ 5 & 4 & 3 & 2 & 1 \\ 5 & 4 & 3 & 2 & 1 \\ 5 & 4 & 3 & 2 & 1 \\ 5 & 4 & 3 & 2 & 1 \\ 5 & 4 & 3 & 2 & 1 \\ 5 & 4 & 3 & 2 & 1 \\ 5 & 4 & 3 & 2 & 1 \\ 5 & 4 & 3 & 2 & 1 \\ 5 & 4 & 3 & 2 & 1 \\ 5 & 4 & 3 & 2 & 1 \\ 5 & 4 & 3 & 2 & 1 \\ 5 & 4 & 3 & 2 & 1 \\ 5 & 4 & 3 & 2 & 1 \\ 5 & 4 & 3 & 2 & 1 \\ 5 & 4 & 3 & 2 & 1 \\ 5 & 4 & 3 & 2 & 1 \\ 5 & 4 & 3 & 2 & 1 \\ 5 & 4 & 3 & 2 & 1 \\ 5 & 4 & 3 & 2 & 1 \\ 5 & 4 & 3 & 2 & 1 \\ 5 & 4 & 3 & 2 & 1 \\ 5 & 4 & 3 & 2 & 1 \\ 5 & 4 & 3 & 2 & 1 \\ 5 & 4 & 3 & 2 & 1 \\ 5 & 4 & 3 & 2 & 1 \\ 5 & 4 & 3 & 2 & 1 \\ & & & \end{array}$

